\title{
IDENTIFICATION OF CRITICAL SUCCESS FACTORS FOR THE IMPLEMENTATION OF THE BLOCKCHAIN PROJECTS IN THE SMART CITIES
}

\author{
Zoran Ćirić ${ }^{1}$ \\ Otilija Sedlak ${ }^{2}$ \\ Stojan Ivanišević ${ }^{3}$
}

DOI: https://doi.org/10.31410/LIMEN.2019.129

\begin{abstract}
The primary objective of this paper is to conduct a systematic literature review to analyse contemporary scientific literature to determine a list of blockchain IT system implementation critical success factors. Scientific literature is available for the critical success factors that are impacting implementation for IT projects in general; however, it is of scientific and practical importance to whether these factors and their influence change when it comes to blockchain projects and even to determine does some additional critical success factors impact the success of the blockchain information system implementation in the smart cities.
\end{abstract}

Keywords: Blockchain, Smart city, Project management, Information systems, Sustainability.

\section{INTRODUCTION}

$\mathrm{B}$ lockchain is one of the most popular buzzwords at the end of the decade. The hype associated with crypto currencies made blockchain technology worldwide famous. The positive aspect of the hype was that many new startups and ideas revolving around the implementation of the blockchain technologies arose. However, this hype did a lot for the blockchain technology spread but also caused a lot of damage to the understanding the nature of this technology and the way it can revolutionize entire business models trough improvement of the information systems. Viewed from the information technology point of view, the blockchain is a new way of data layer organization, not some magical new paradigm that will change everything and make everything else obsolete. Storing data in encrypted, anonymised, append-only, distributed, a peer-to-peer database that has computer algorithm for deciding what truth instead of arbitrary central authority is a revolutionary leap, but it has to be viewed as an important part of current information technologies and systems not per se. Blockchain projects are already implemented in many areas, including information systems in smart cities. They are implemented by IT projects managers and perceived as IT project which they are. The goal of this paper is to attempt to identify some additional project implementation success factors that are native to the blockchain projects within smart cities or the blockchain projects in general in case that data on blockchain projects is scarce. Since blockchain theory is the novel subject of the scientific literature, practical example and use cases are even more scarce, the authors of these papers will attempt to find and examine all available source of information including non-scientific articles and data available on the internet.

\footnotetext{
University of Novi Sad, Faculty of Economics Subotica, Segedinski put 9-11, Subotica, Serbia University of Novi Sad, Faculty of Economics Subotica, Segedinski put 9-11, Subotica, Serbia JKP Informatika Novi Sad, Bul. cara Lazara 3, Novi Sad, Serbia
} 


\section{BLOCKCHAIN TECHNOLOGY IN THE SMART CITY CRITICAL SUCCESS FACTORS}

The authors analysed the available scientific literature and other available literature to find any additional CSF related to blockchain projects specifically or to determine the deviation of strength for any CSF in the list.

\begin{tabular}{|c|c|}
\hline $\begin{array}{l}\text { Architecture - } \\
\text { Technology }\end{array}$ & $\begin{array}{l}\text { Software engineers should define criteria for selecting the most appropriate blockchain implementation, } \\
\text { evaluating the adoption of sidechain technology, or the implementation of an ad-hoc blockchain (Porru, } \\
\text { 2017). } \\
\text { Enhancements in blockchain design are needed to improve scalability by reducing latency, increasing } \\
\text { throughput and enhancing security. Progress in this domain will expand the technology's adoption (Schat- } \\
\text { sky \& Muraskin, 2015). } \\
\text { Integration in IT architecture, In-house/ internal development, Flexible infrastructure (Holotiuk \& Moor- } \\
\text { mann) }\end{array}$ \\
\hline $\begin{array}{l}\text { Blockchain size } \\
\text { - throughput }\end{array}$ & $\begin{array}{l}\text { As the blockchain adoption increases, blockchains will grow exponentially, commonly referred to as } \\
\text { blockchain bloat (Swan, 2015). To become a mainstream technology, blockchains of the future must be } \\
\text { scalable and fast (Schatsky \& Muraskin, 2015). The size of the blockchain ledger is already more than the } \\
\text { capability of some of smaller devices and may lead to making a vast part of the public unable to participate } \\
\text { or delays in processing transactions (Innovalue, 2015). } \\
\text { The blockchain technology is still in the early stages of development and faces several technical limitations } \\
\text { such as throughput (a theoretical current maximum number is seven transactions per second), latency } \\
\text { (each block takes } 10 \text { min to process which means at least } 10 \text { min needed for your transaction to be con- } \\
\text { firmed), and size and bandwidth (long time needed to download the entire blockchain) (Wang et all, 2017). } \\
\text { Increased efficiency is anticipated, as "transaction costs are expected to decrease" (with blockchain) } \\
\text { (Ølnes et all, 2017). }\end{array}$ \\
\hline Business model & $\begin{array}{l}\text { Traditional business models might not seem applicable to the blockchain, since the whole point of decen- } \\
\text { tralized peer-to-peer models is that there are no facilitating intermediaries, whereas most of the businesses } \\
\text { are formed around the concept of intermediation (to reduce total transaction cost for the customer while } \\
\text { earning a fee for themselves) (Prasad et all, 2018). However, there are many worthwhile applications of } \\
\text { blockchains even in a traditional business (Swan, 2015). } \\
\text { One factor that drives the interest in distributed ledger-based methods is the ease with which they can be } \\
\text { added to existing workflows and data processing lifecycles (Anjum et all, 2017). }\end{array}$ \\
\hline $\begin{array}{l}\text { Cloud services } \\
\text { integration }\end{array}$ & $\begin{array}{l}\text { A key success factor for blockchains in an enterprise is middleware - integration of blockchains with each } \\
\text { other and with many other systems in real-time, using different technologies and communication protocols } \\
\text { (Everest Group, 2016). }\end{array}$ \\
\hline CASE Tools & $\begin{array}{l}\text { Creation of software tools for smart contract languages. The implementation of Smart Contract Develop- } \\
\text { ment Environments (SCDEs)-the blockchain-oriented declination of IDEs-might be pivotal for the build- } \\
\text { ing and diffusion of expertise (Porru, et all, 2017). }\end{array}$ \\
\hline $\begin{array}{l}\text { Cost- } \\
\text { effectiveness }\end{array}$ & $\begin{array}{l}\text { Therefore, blockchain-based cloud services must be highly cost-efficient, even while scaling up and wast- } \\
\text { ing many computational resources (mining) by design (Swan, 2015). } \\
\text { Not all blockchain projects result in a reduction of costs and blockchain is just one part of a complete solu- } \\
\text { tion (Robben \& Verslype). }\end{array}$ \\
\hline $\begin{array}{l}\text { Energy } \\
\text { efficiency }\end{array}$ & $\begin{array}{l}\text { Blockchain mining draws an enormous amount of energy, estimated to be } \$ 15 \mathrm{~m} \text { per day or even more, to } \\
\text { compute and verify transactions securely and with trustworthiness (Swan, 2015). There have been some } \\
\text { work and proposals to improve energy efficiency through economic models (Wang \& Liu, 2015), more } \\
\text { efficient block design (Paul et all, 2014) and faster Bitcoin mining through the simultaneous usage of CPUs } \\
\text { and GPUs (Anish, 2014). }\end{array}$ \\
\hline $\begin{array}{l}\text { Industry } \\
\text { collaboration }\end{array}$ & $\begin{array}{l}\text { Blockchain will be successful if a strong community and value-creating network can be formed (Prasad } \\
\text { et all, 2018). This will need shared solutions and shared solutions will require governance and consensus } \\
\text { around technology choices. Industry leaders must collaborate to design the right solutions and should form } \\
\text { consortia and work with regulators early on (McKinsey, 2015). }\end{array}$ \\
\hline $\begin{array}{l}\text { Legislation } \\
\text { - Regulatory } \\
\text { clarity }\end{array}$ & $\begin{array}{l}\text { Regulatory clarity (or lack thereof) will decide whether the blockchain industry will develop into a full- } \\
\text { fledged industry (or not). Multiple countries have banned or continued to deliberate cryptocurrency-related } \\
\text { issues (Swan, 2015). Recently, the Union Budget of India } 2018 \text { declared cryptocurrencies to be illegal } \\
\text { tender but supported exploration of blockchain technology (Mathur, 2018). } \\
\text { Forthcoming regulation is likely to influence the future of blockchain as the technology can store substan- } \\
\text { tial amounts of sensitive data, including payment information and customer data (Holotiuk \& Moormann). }\end{array}$ \\
\hline Metrics & $\begin{array}{l}\text { Due to the distributed nature of the Blockchain, specific metrics are required to measure complexity, com- } \\
\text { munication capability, resource consumption (e.g. the so-called gas in the Ethereum system), and overall } \\
\text { performance of blockchain systems (Porru et all, 2017). }\end{array}$ \\
\hline
\end{tabular}




\begin{tabular}{|c|c|}
\hline $\begin{array}{l}\text { Modelling } \\
\text { languages }\end{array}$ & $\begin{array}{l}\text { Diagrams such as the Use Case Diagram, Activity Diagram, and State Diagram could not effectively rep- } \\
\text { resent the blockchain environment (Porru et all, 2017). } \\
\text { Currently, the industry is not providing sufficient use cases which present potential applications within the } \\
\text { organization (Ølnes et all, 2017). } \\
\text { Focus on the customer when designing use cases (Holotiuk \& Moormann). }\end{array}$ \\
\hline $\begin{array}{l}\text { Organisational } \\
\text { Structure }\end{array}$ & $\begin{array}{l}\text { The successful adoption of blockchain requires a lot of organisational support in various forms. In all cas- } \\
\text { es, the blockchain adoption is widely supported by the top management and considered important enough } \\
\text { to invest in the adoption (Holotiuk \& Moormann). }\end{array}$ \\
\hline Privacy & $\begin{array}{l}\text { There are studies to show experimental evidence on the lack of anonymity in the Bitcoin network and pos- } \\
\text { sibility to do transaction linking to IP addresses (Moser et all, 2013; Koshy et all, 2014; Feld et all, 2014). } \\
\text { The success of the Estonian medical record blockchain project will depend upon its ability to keep medical } \\
\text { records private while at the same time widely available to medical providers and insurance companies } \\
\text { (Heston, 2017). } \\
\text { Loss of privacy, trust and confidentiality (Bhargava et all, 2013). }\end{array}$ \\
\hline & $\begin{array}{l}\text { The project management teams are responsible for organisational tasks concerning blockchain (Holotiuk } \\
\text { \& Moormann). }\end{array}$ \\
\hline Rich ecosystem & $\begin{array}{l}\text { Blockchains include several different types of participants as a business network, and its real value is } \\
\text { achieved when these business networks grow (IBM, 2017). }\end{array}$ \\
\hline Security & $\begin{array}{l}\text { A Blockchain must guarantee data integrity and uniqueness to ensure Blockchain-based systems are trust- } \\
\text { worthy. The same group of authors, recommend software review as additional development methodology } \\
\text { (Porru et all, 2017). } \\
\text { Blockchain, especially public ones, has some potential security issues (Swan, 2015). } \\
\text { An improved security perception will be a CSF of blockchain (Prasad et all, 2018; Riggins \& Wamba, } \\
\text { 2015). }\end{array}$ \\
\hline ment & $\begin{array}{l}\text { Development of sidechains, alternative blockchains with additional features but still linked to Bitcoin, } \\
\text { could be a CSF for the broader adoption of blockchain technology (Bogart \& Rice, 2015). }\end{array}$ \\
\hline Standardisation & $\begin{array}{l}\text { Industry Standards will need to emerge for better enterprise adoption of blockchain technologies (Everest } \\
\text { Group, 2016). } \\
\text { There are many types of blockchain available on the market. Consequently, experts are unsure "if block- } \\
\text { chain will become a standard in the banking industry." (Ølnes et all, 2017). }\end{array}$ \\
\hline Team skills & $\begin{array}{l}\text { The Blockchain sector will need professional figures with a well-defined skills portfolio com-prising fi- } \\
\text { nance, law, and technology expertise. Skilling up current resources and/or hiring blockchain skills will be } \\
\text { a CSF for better returns on blockchain investments and, therefore, increased blockchain adoption (Porru } \\
\text { et all, 2017). } \\
\text { Enterprises will need a smart contracts talent pool that can connect legal text to business logic and convert } \\
\text { that to a programmed smart contract on blockchain (Everest Group, 2016). } \\
\text { An acute shortage of available talent for blockchain industry jobs has been reported as a major problem } \\
\text { preventing wider growth and use of the technology (Castillo, 2017). } \\
\text { Skilled experts in the area of blockchain that may fill existing knowledge gaps are currently expensive and } \\
\text { rare in the market (Holotiuk \& Moormann). }\end{array}$ \\
\hline $\begin{array}{l}\text { User control of } \\
\text { data }\end{array}$ & $\begin{array}{l}\text { User control on data will be an important driver for the success of blockchain-based cloud services, as } \\
\text { that will help assuage user's privacy concerns with a decentralized system with multiple (and potentially } \\
\text { unverified) nodes (Bogart \& Rice, 2015; Swan, 2015). }\end{array}$ \\
\hline $\begin{array}{l}\text { User } \\
\text { engage }\end{array}$ & $\begin{array}{l}\text { User engagement is one of the primary success factors defining the success of blockchain technology } \\
\text { (Prasad et all, 2018). } \\
\text { Blockchain is still an emerging technology for most construction people. Lack of awareness and under- } \\
\text { standing prevents the diffusion of this technology. There are many issues to be resolved before individuals } \\
\text { would feel comfortable storing their personal records in a decentralised manner with a pointer and possibly } \\
\text { access via the blockchain (Wang et all, 2017). }\end{array}$ \\
\hline
\end{tabular}

\section{CONCLUSION AND FURTHER RESEARCH}

The currently available scientific literature on critical success factors for the software development projects can be compared to the list of CSF (critical success factors) authors created. Authors in the scientific literature did extensive analysis and created a scientific viewpoint on the subject of critical success factors for the project implementation (Sudhakar, 2012; Müller \& Jugdev, 2012; Ram \& Corkindale, 2014). G. Sudhakar (2012) in an extensive literature review identified 35 critical success factors based on the past empirical and theoretical studies that increase the project success. Software development and implementation CSF will be compared to the factors found in this research to detect the overlap of CSF related to blockchain and 
CSF related to software development and implementation projects. The overlapping CSF is Architecture -Technology, Business model, Cost-effectiveness, Cloud services integration, Organisational structure, Project management, Team competence and User engagement. The rest of the factors are primarily associated with the blockchain technology as a factor. Blockchain specific CSF are as follows: Blockchain size - throughput, blockchain development and testing CASE Tools, Energy efficiency, Industry collaboration, Legislation - Regulatory clarity, Metrics, Modeling languages, Privacy, Rich ecosystem, Security, Sidechain Development, Standardization, User control of data.

In this work software, development and implementation are viewed holistically because of their inseparable nature (no software is developed not to be implemented, and successful implementation is the successful result for any software development project). The created list is just a literature review of the available literature and has no pretensions to be considered as final and whole. This list is a starting point for further research. Additionally, the research gathered results from many areas that contribute to smart city components, e.g. supply chains that contribute to the mobility of the smart cities but was also broadened by all other available resources related to the CSF of the blockchain projects.

Further research should tie blockchain CSF more tightly and specifically to the blockchain projects in the smart cities and also try to use the scientific method to extract knowledge from domain experts that are not researchers.

\section{REFERENCES}

Anish, D.J. (2014), "Bitcoin mining acceleration and performance quantification", IEEE 27th Canadian Conference on Electrical and Computer Engineering, pp. 1-6.

Anjum, A., Sporny, M., \& Sill, A. (2017). Blockchain standards for compliance and trust. IEEE Cloud Computing, 4(4), 84-90.

Bhargava, B., Ranchal, R., \& Ben Othmane, L. (2013). Secure information sharing in digital supply chains (pp. 1636-1640). Presented at the $3^{\text {rd }}$ IEEE Int. Adv. Comput. Conf., IEEE. https://doi. org/10.1109/IAdCC.2013.6514473

Bogart, S. and Rice, K. (2015), "The blockchain report: welcome to the internet of value", available at www.the-blockchain.com/docs/The\%20Blockchain\%20Report \%20-\%20Needham\%20 (Huge\%20report).pdf

Castillo, M.d. (2017), "The lack of blockchain talent is becoming an industry concern", available at: www.coindesk.com/blockchain-hiring-difficulties-becoming-industry-concern/ (accessed March 20, 2017).

Everest Group (2016), "Smart contracts on a distributed ledger - life in the smart lane", available at: www2.everestgrp.com/Files/previews/Smart\%20Contracts\%20on \%20Distributed $\% 20$ Ledger\%20-\%20Life\%20in\%20the\%20Smart\%20Lane.pdf

Feld, S., Schnfeld, M. and Werner, M. (2014), "Analyzing the deployment of Bitcoin's $\{$ P2P $\}$ network under an AS-level perspective", Procedia Computer Science, Vol. 32, pp. 1121-1126.

Goparaju Purna Sudhakar, (2012), „A model of critical success factors for software projects”, Journal of Enterprise Information Management, Vol. 25 Iss 6 pp. 537 - 558, Permanent link to this document: http://dx.doi.org/10.1108/17410391211272829

Heston, T. (2017). A case study in blockchain healthcare innovation.

Holotiuk, F., \& Moormann, J. Dimensions, Success Factors and Obstacles of the Adoption of Blockchain Technology. 
IBM (2017), "IBM names three blockchain adoption principles essential for every CEO to consider", available at www-03.ibm.com/press/us/en/pressrelease/52018.wss

Innovalue, L.L. (2015), "Blockchain and financial services: industry snapshot and possible future developments", available at www.the-blockchain.com/docs/Locke\%20Lord\%20\%20Blockchain\%20in\%20Financial\%20Services\%202015.pdf

Jiwat Ram, David Corkindale, (2014), „How “critical” are the critical success factors (CSFs)?: Examining the role of CSFs for ERP”, Business Process Management Journal, Vol. 20 Iss 1 pp. 151-174 http://dx.doi.org/10.1108/BPMJ-11-2012-0127

Koshy, P., Koshy, D. and McDaniel, P. (2014), "An analysis of anonymity in Bitcoin using P2P network traffic", in Christin, N. and Safavi-Naini, R. (Eds), Financial Cryptography and Data Security. Lecture Notes in Computer Science, Vol. 8437, Springer, Berlin, Heidelberg, pp. 469-485.

Mathur, N. (2018), "Budget 2018: Arun Jaitley outlaws cryptocurrency", available at www.livemint.com/Politics/xmBDOdP2H2hbXH7eV1VTqL/Budget-2018-Crypto-currencies-illegal-will-eliminate-their.html

McKinsey (2015), "Beyond the hype: blockchains in capital markets", available at www.mckinsey. com/industries/financial-services/our-insights/beyond-the-hype-blockchains-in-capital-markets

Moser, M., Bohme, R. and Breuker, D. (2013), "An inquiry into money laundering tools in the Bitcoin ecosystem”, eCrime Researchers Summit (eCRS), San Francisco, CA, pp. 1-14.

Ølnes, S., Ubacht, J., \& Janssen, M. (2017). Blockchain in Government: Benefits and implications of distributed ledger technology for information sharing.

Paul, G., Sarkar, P. and Mukherjee, S. (2014), "Towards more democratic mining in Bitcoins", in Prakash, A. and Shyamasundar, R. (Eds), Information Systems Security. Lecture Notes in Computer Science, Vol. 8880, Springer, Cham, pp. 185-203.

Porru, S., Pinna, A., Marchesi, M., \& Tonelli, R. (2017, May). Blockchain-oriented software engineering: challenges and new directions. In 2017 IEEE/ACM 39th International Conference on Software Engineering Companion (ICSE-C) (pp. 169-171). IEEE

Prasad, S., Shankar, R., Gupta, R., \& Roy, S. (2018). A TISM modelling of critical success factors of blockchain-based cloud services. Journal of Advances in Management Research.

Ralf Müller, Kam Jugdev, (2012), „Critical success factors in projects: Pinto, Slevin, and Prescott - the elucidation of project success", International Journal of Managing Projects in Business, Vol. 5 Iss 4 pp.757-775 http://dx.doi.org/10.1108/17538371211269040

Riggins, F. J., \& Wamba, S. F. (2015). Research Directions on the Adoption, Usage, and Impact of the Internet of Things through the Use of Big Data Analytics (pp. 1531-1540). IEEE. https:// doi.org/10.1109/HICSS.2015.186

Robben, F., \& Verslype, K. Blockchain: concept, critical success factors and possibilities in the food chain.

Schatsky, D. and Muraskin, C. (2015), "Beyond Bitcoin: Blockchain is coming to disrupt your industry", available at https://dupress.deloitte.com/dup-us-en/focus/signals-for-strategists/ trends-blockchain-bitcoin-security-transparency.html\#endnote-30

Swan, M. (2015), Blockchain: Blueprint for a New Economy, O'Reilly, Sebastopol, CA.

Wang, J., Wu, P., Wang, X., \& Shou, W. (2017). The outlook of blockchain technology for construction engineering management. Frontiers of engineering management, 67-75.

Wang, L. and Liu, Y. (2015), "Exploring miner evolution in Bitcoin network", in Mirkovic, J. and Liu, Y. (Eds), Passive and Active Measurement. Lecture Notes in Computer Science, Vol. 8995, Springer, Cham, pp. 290-302. 